\title{
Archipel
}

ARCHIPEL Études interdisciplinaires sur le monde insulindien

99 | 2020

Varia

\section{Performing Arab Saints and Marketing the Prophet: Habaib and Islamic Markets in Contemporary Indonesia}

Mise en scène de saints arabes et commercialisation du Prophète: Habaib et marchés islamiques dans l'Indonésie contemporaine

\section{Syamsul Rijal}

\section{OpenEdition}

\section{Journals}

\section{Electronic version}

URL: http://journals.openedition.org/archipel/1719

DOI: 10.4000/archipel. 1719

ISSN: 2104-3655

\section{Publisher}

Association Archipel

\section{Printed version}

Date of publication: 15 July 2020

Number of pages: $189-213$

ISBN: 978-2-910513-83-2

ISSN: 0044-8613

\section{Electronic reference}

Syamsul Rijal, "Performing Arab Saints and Marketing the Prophet: Habaib and Islamic Markets in Contemporary Indonesia", Archipel [Online], 99 | 2020, Online since 02 June 2020, connection on 15 March 2021. URL: http://journals.openedition.org/archipel/1719 ; DOI: https://doi.org/10.4000/ archipel. 1719 
SYAMSUL RIJAL ${ }^{1}$

\section{Performing Arab Saints and Marketing the Prophet: Habaib and Islamic Markets in Contemporary Indonesia}

\section{Introduction ${ }^{2}$}

Post-Soeharto Indonesia has witnessed the proliferation of young Hadhrami Arab preachers along with their sermon groups (majelis taklim and majelis dzikir). They are popularly called habib (sing.) or habaib (pl.) indicating their genealogical link to the Prophet. ${ }^{3}$ The habaib generally wear white turbans (imamah) and long robes (jubah), and some hold a walking stick in their hand emulating the Prophet's appearance. They usually deliver sermons on stage with a number of other habaib and local preachers accompanied by a group of traditional Arab musical performers (hadhrah). Popular preachers such as Habib Hasan b. Ja'far Assegaf, the late Habib Munzir b. Fuad Al-Musawa, Habib Syech b. Abdul Qadir Assegaf, and Habib Noval b. Muhammad

1. The Faculty of Dakwah and Communication, UIN Syarif Hidayatullah Jakarta.

2. This article is a revised and improved part of my $\mathrm{PhD}$ thesis submitted to the Australian National University in 2016. I would like to thank my former thesis supervisor, Associate Professor Greg Fealy, and my advisors, Associate Professor Marcus Mietzner and Associate Professor Ronit Ricci, for their invaluable feedbacks and enduring support during the earlier formation of this draft. I also thank the reviewers of Archipel in Paris for their constructive feedbacks on improving my article draft. Finally, I am indebted to Thuy Pham for her kind assistance in correcting and polishing my article draft.

3. In Indonesian use, habib (sing.) or habaib (pl.) refer to an honorific title given to religiously learned men of Hadhrami-Arab descent who claim a genealogy to the Prophet Muhammad, while sayyid (lord) refers to a social status for the descendants of the Prophet who have lived in Hadhramaut, Yemen, and other countries. 
Alaydrus have gained a high profile among traditionalist Muslims in urban areas, most notably in Jakarta, Central Java, and East Java. Their public sermons usually attract thousands and frequently create traffic jams as people and vendors of religious merchandises crowd onto nearby streets. This phenomenon indicates two important aspects: the popularity of Arab-sayyid culture in public preaching and the rising demand for public preaching among Indonesian Muslims.

Several celebrity preachers have been rising in Indonesia with their own distinctive styles and approaches. Many preachers such as Abdullah Gymnastiar (Aa Gym), the late Jefrie al-Buchori (Uje), Yusuf Mansur, the late Arifin Ilham, Maulana Nur, Mamah Dedeh, Abdul Somad, and Adi Hidayat have turned into celebrities due to their roles on national television and social media. Due to the demands for entertainment and information, many TV stations offer more opportunities for preachers who have media literacy and good mass communication skills (Muzakki 2008: 210). Each celebrity preacher has his own trademark of religious entrepreneurship: Aa Gym uses simple everyday language in his preaching concentrating on 'heart development' or what he called 'Manajemen Qalbu'; the late Arifin Ilham had a skill in leading mass gatherings reciting prayers and chants; Yusuf Mansur has a preaching style that promotes the power of philanthropy, especially alms giving (sedekah) for achieving prosperity; the late Uje had been skilled in using 'street talk' (bahasa gaul) and singing Islamic songs (Fealy 2008: 25-26); while other preachers such as Maulana Nur and Abdul Somad employ humour in their preaching. A study by Hew Wai Weng also points to the rise of Chinese Muslim preachers who capitalise on their Chineseness while using a mixture of different performing styles to lift their popularity (Hew 2018: 120-158).

Several scholars have studied the shift of religious authority from the traditionally trained preachers to lay preachers who have created what Hoesterey calls "innovative claims of religious authority" (Hoesterey 2008: 97). According to Julian Millie, the rising Muslim televangelists in Indonesia, most of whom lack formal religious qualifications, "break the mold of the classic or old-style religious scholars (ulama)" (Millie 2012: 123). While most scholars have focused their attention on the new preachers who broke away from tradition, this study discusses new preachers who style themselves as traditionalist ulamas and saints (wali). In recent years, there has been a growing number of traditionalist preachers in urban areas, especially in Jakarta, thanks to a variety of new media technologies and marketing strategies. Focusing on habaib preachers and their sermon groups, I will take the case of Habib Hasan b. Ja'far Assegaf and analyse how he has emerged as a popular preacher by examining his profile and autobiography, sermons, dakwah performance styles, and his religious branding. This article argues that habaib rely more 
on performance and entertainment than oratorical competence in attracting followers. Their appeal lies in their distinctive appearance, which combines symbols of traditionalism, sainthood, and Arabness. The habaib perform as traditionalist scholars and Arab saints, a classical style that makes them look charismatic and authoritative to audiences. This study confirms Hilary Kalmbach's analysis of new religious intellectuals in Egypt that "performance plays a key role in the legitimation of Islamic authority" (Kalmbach, 2015, p. 163). This notion implies that having a traditional education and religious capital (as habib) is not sufficient to gain popularity; a preacher also needs to perform as traditionalist scholar and saint to meet the expectation of his audiences.

The major data in this article is based on my fieldwork that I undertook for nine months in Jakarta in 2013 with some update observations in 2019. My fieldwork included a number of interviews and informal conversations with habaib, sermon groups' staffs, and their followers, as well as participatory observations in numerous religious events organized by various sermon groups in Jakarta, most notably the Nurul Musthofa and Majelis Rasulullah. Besides, I also accessed and analysed self-marketing books, Islamic magazines, and various merchandises that have been sold and circulated within traditionalist Muslims, especially when public sermons have been held in a particular venue. This study, therefore, employs a qualitative research that combines ethnography and textual analysis to understand the behaviour of religious elites in preaching and marketing.

The first part of this article provides a brief discussion on majelis taklim and analyses its connection with socio-political context and religious market in Indonesia. The second part discusses Habib Hasan b. Ja'far Assegaf along with his sermon group in Jakarta. It analyses how he founded and developed his sermon group as well as popularised his dakwah among Jakartan Muslims. The third part looks at the growing popularity of habaib along with their majelis by underlining three aspects of their commodification: the performative aspect of sainthood and Arab ethnicity; the role of new media and musicality in popularising their dakwah; and the reference to the Prophetic symbols in their branding.

\section{Majelis Taklim, Religious Market and New Media}

Majelis taklim is a popular venue for Indonesian Muslims to receive Islamic knowledge by listening to a single preacher or several preachers. Abaza defines it as "a meeting, sitting or council where the process of ta'lim (education) takes place" (Abaza 2004: 179). Majelis taklim is often associated with Islamic study groups, religious learning forums, preaching gatherings, private gatherings for religious teaching, and as salon-style religious discussion groups (Winn 2012). In the Muslim world, majelis taklim is quite similar with halaqah, a common term for Islamic study circle. However, the 
term and form of majelis taklim is distinctive and only found in Indonesia. While it is informal and open to the public, majelis is usually convened in mosques, houses, meeting rooms in hotels or offices, or in public area. Many preachers or organizers of majelis taklim usually provide a special large room in their houses with mats on the floor (Abaza 2004: 179). There is no clear history on the origin of the majelis in Indonesia, yet some habaib refer to the Majelis Taklim Habib Ali Kwitang in Jakarta as the pioneering majelis in Indonesia. The majelis was founded by Habib Ali b. Abdurrahman al-Habsyi (popularly called as Habib Ali Kwitang) at the end of the 19th century and has been continued by his descendants up to the present. Many local kiais and large number of participants attended the majelis throughout history (Alatas 2011: 57). In the past, majelis taklim such as Majelis Habib Ali Kwitang were led by a senior habib whose religious knowledge was acknowledged by local communities. Their popularity with the Muslim public was apparently due to their charisma and their mastery of traditional Islamic knowledge.

Majelis taklim gatherings had received national media attention from the 1990s onwards at the time when Islamic revival shaped the social and cultural spaces of Indonesian Muslims (Winn 2012). Majelis has been more popular among middle-aged and married Muslim women who not only want to study Islam but also to spend time with their friends and neighbours. According to Phillip Winn (2012), "participation in majelis taklim attracted considerable legitimacy as a vehicle for religiously engaged contemporary Muslim women to contribute to national life". Due to its popularity, majelis spread in many provinces. According to the directorate of Islamic education, there were 153,357 majelis taklim in Indonesia in 2006 (Winn 2012). As the number of participants increased, 735 majelis taklim agreed to establish the Body for Contacts among majelis taklim (Badan Kontak Majelis Taklim, BKMT) in Jakarta in 1981. It was chaired by the late Prof. Tutty Alawiyah (1942-2016), a daughter of the late Jakartan ulama, K.H. Abdullah Syafi'i (1910-1985). According to its website, the special objective of BKMT is "to increase the ability and role of majelis taklim in enhancing the greatness of Islam (syiar) and developing the intellectual capacity of the umma. ${ }^{4}$

Although in its development majelis taklim was largely associated with the domain of Muslim women, there were a few majelis taklim which had maleonly followers or mixed sex meetings. The oldest habaib majelis in Jakarta, Majelis Habib Ali Kwitang, for instance, consists of male and female audiences who are segregated during the sermon. Another old majelis, such as Al-Kifahi Al-Tsaqafi, in Bukit Duri, Jakarta, also has both men and women as followers, but each of group has a different schedule. The common characteristic of majelis audiences in the past is that they consisted predominantly of older people and very few youths and teenagers.

4. See more details at http://bkmt.or.id/index/sejarah-bkmt/ (accessed 8 October 2019). 
The booming popularity of young habaib-led majelis taklim among young Muslims has become a new phenomenon in post-Soeharto Indonesia. While the older generation of habaib prefer to keep a low profile, the new generation actively promote themselves. There are several points that distinguish them from earlier generations of habaib preachers. Firstly, most of the new preachers are young, ranging from 20 to 30 years at the start of their preaching career. Many of them graduated from Hadhramaut, Yemen, while some graduated from traditional Islamic schools (pesantren) in Java. Secondly, the new preachers tend to establish their own majelis taklim, becoming the pivotal figure in their organisation, and utilising advertising and the internet to promote their sermons. The newly established majelis often have a logo or brand, flags, a headquarters, official website, and religious merchandise. They also have a multimedia team, young staff members and volunteers to help organise their events. Thirdly, many young habaib preachers emphasise their distinctive status by wearing a white turban, a long white dress, and a shawl (mostly green) on their shoulders. Finally, most of the participants in this type of majelis are young people, both men and women, ranging from 12 to 30 years and mostly coming from the traditionalist Muslim families. Participants usually wear the uniform jackets of the majelis showing their commitment and their linked identity to the majelis.

The resurgence of habaib dakwah cannot be isolated from the context of competing authority among Muslim groups. In the evolving public sphere and increasingly deregulated market, we have witnessed the rapid expansion of various Muslim groups that compete for followers (Meuleman 2011). They actively organise public activities, sell religious products, and spread their religious messages through the new media. Various interpretations of religious messages, ranging from puritanical to liberal ones, have been disseminated in print media and the internet. The advanced development in technology and communication as well as globalization has allowed the flow of ideas from overseas. Several new Muslim movements rooted in the Middle East have expanded their ideology through dakwah and education in Indonesia. Among the new Islamic movements, Salafi groups are prominent in preaching Islamic purification through sermons, education and new media. ${ }^{5}$ They also denounce the beliefs and rituals of traditionalist Muslims which they regarded as unlawful innovation (bid'ah). Traditionalist Muslims, who constitute the Muslim majority in Indonesia, believe that Salafi dakwah has been a challenge to their tradition. The community became increasingly concerned when several incidents appeared to threaten their position, such as the taking over of traditionalist mosques, the denouncing of unlawful innovation (bid'ah) in

5. For a good account on the early and contemporary development of Salafi in Indonesia, see Hasan (2006), Wahid (2014), Jahroni (2015), Sunarwoto (2016), and Chaplin (2018). 
their religious practices, and Salafi 'penetration' into Muslim organisations (Nuhrison 2010, Saparudin \& Emawati 2018). ${ }^{6}$

In a situation where traditionalist Muslims were under the perceived 'threat' of Salafi and other new Muslim groups, there was a growing demand for dakwah and religious marketing within the traditionalist community. Religious marketing in this sense refers to "a competition for followers who can be captured on the basis of strong public presence and seducing and convincing rhetoric, performance, and imagery" (de Witte et. al. 2015: 120). In this sense, dakwah and religious markets are a medium for preachers and religious groups to attract followers. This resonates with Pattana Kitiarsa's view (2008 and 2010) which counters secularisation theory emphasising the triumph of market over religion. He contends that "market and media make religions more accessible to the public and convert religions into popular cultural practice in modern societies..." (Kitiarsa 2010: 579). This point of view is adopted by the majority of habaib preachers who seek to popularise their traditionalist Islam through new media and markets. Realising the growing demand for dakwah from traditionalist communities, habaib have responded by conducting dakwah through sermon groups (majelis taklim) in urban areas. They called on Muslims to strengthen their Sunni belief through regular participation in majelis taklim so that they can protect themselves from the influence of Salafi and other 'deviant' groups.

The increasing competition for followers led habaib to creatively brand their traditionalist dakwah and fashion it in order to meet the aspirations of urban Muslim youth. Habaib are determined to establish sermon groups (majelis taklim) that are totally different from conventional ones. The new sermon groups are structured in such a way as to offer young Muslims a venue to express their aspirations through dakwah activism and identity expressions. The habaib fashioned their majelis taklim to be like a public performance and entertainment that give followers active roles. As a result, the majelis is no longer seen as a serious place for religious learning, but rather a pleasurable place for socialising, chanting, and singing praises of the Prophet accompanied by traditional musical performance.

\section{Habib Hasan b. Ja'far Assegaf and His Sermon Group}

Habib Hasan, founder of the Majelis Nurul Mustafa (Council of the Light of the Chosen One), was born in Bogor, West Java, in 1977. He grew up in a sayyid

6. Some habaib whom I interviewed and observed in 2013 worried about the expansion of Salafi dakwah activities in Indonesia. A popular young preacher in Solo, Habib Noval b. Muhammad Alaydrus, has criticized Salafi-Wahhabism and defended traditionalist Islam through his sermons and his books. See, for instance, his book (2011), Ahlul Bid'ah Hasanah: Jawaban Untuk Mereka Yang Mempersoalkan Amalan Para Wali (The Doers of Good Innovation: The Answers for those who question the practices of saints). 
family that attached great importance to their children's religious practice and education. Habib Hasan has a genealogical connection to a charismatic sayyid ulama in Bogor, Habib Abdullah b. Muhsin Al-Attas, through his mother Syarifah Fatmah b. Hasan. He spent his childhood in the village of Keramat Empang where the grave of his grandfather, Habib Abdullah, is located. The grave has been venerated and visited by many ulamas both from Indonesia and other countries because Habib Abdullah is revered as a wali (saint) (Mauladdawilah 2010: 38). Most of Habib Hasan's education was shaped by Indonesian ulamas, both Hadhrami and non-Hadhrami. He received his early education from his father, Habib Ja'far b. Umar Assegaf, who was familiar with the practices and rituals of tariqa Alawiya (the spiritual path of Alawi ancestors). Habib Hasan also studied with local Hadhrami ulamas such as Syeikh Usman Baraja, Abdul Qadir Basalamah, and Syeikh Ahmad Bafadhal (Mauladdawilah 2010: 39).

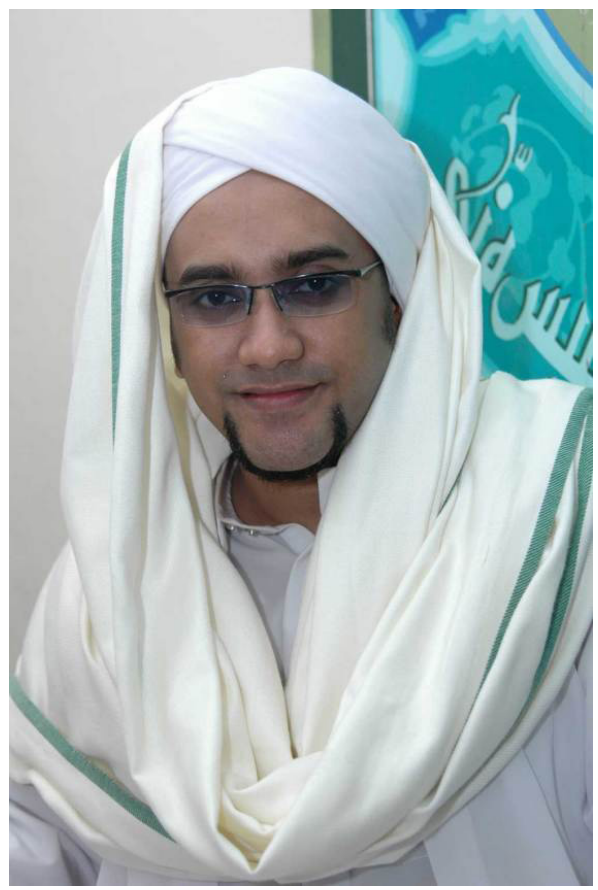

Fig. 1. Photo of Habib Hasan b. Ja'far Assegaf Source: www.pecintaassegaf.wordpress.com.

Habib Hasan spent his formal education in traditional religious schools (pesantren) in Malang, East Java, starting with the Pesantren of Darul Hadith Al-Faqihiyyah, a traditional school established by Habib Abdul Qadir b. Ahmad bil-Faqih. Many habaib and kiais sent their children to that pesantren 
because of the high reputation of its founder who was well known for his expertise in Islamic studies, especially in ulum al-hadith (Science of Prophetic Tradition). After two years, Habib Hasan transferred to Pesantren Darut Tauhid, a pesantren that was also established and run by an Indonesian Arab Syeikh, Abdullah b. Awadh Abdun (alKisah, February 24, 2008). He also had the opportunity to study at the Tarbiyah Faculty of the State Institute of Islamic Studies (IAIN) Sunan Ampel (now State Islamic University of Malang) (Zamhari and Howell 2012: 56). After two years in Darut Tauhid, Habib Hasan returned to Bogor to accept his grandfather's offer to send him to study in Hadhramaut. Sadly, this plan came to nothing when his grandfather died. Instead of travelling to Hadhramaut, he continued to gain Islamic knowledge through informal study clubs (majelis taklim) of habaib in Jakarta, such as the majelis taklim of Habib Abdurrahman b. Ahmad Assegaf and of Habib Ali b. Abdurrahman Assegaf. Besides, he also studied with local kyais such as KH. Syafii Hadzami, KH. Dimyati in Banten, KH. Maman Satibi in Cianjur, KH. Buya Yahya in Bandung, KH. Muallim Shaleh in Bogor, and other ulamas in Jakarta (Mauladdawilah 2010: 48).

Habib Hasan started his religious teaching and preaching activities in Bogor in 1998 after gaining inspiration from what he claimed were his 'spiritual experiences'. When staying in Bogor, Habib Hasan isolated himself from social life, a phase which he called 'uzlah' (self-seclusion from people). He claimed that for a year and three months, he spent all his time on three main acts of religious devotion: regular visits to the grave of his grandfather, Habib Abdullah b. Muhsin Al-Attas; conducting congregational prayers in a nearby mosque; and regular contemplation and wirid (reciting passages of praise and prayers to God). He recalled that it was through these acts of devotion that he gained inspiration and guidance (bisyarah) to undertake religious teaching and preaching to Muslims (Mauladdawilah 2010: 53). With the request from his father and support from local kyais and ustadz, Habib Hasan began religious teaching and preaching by moving from one village to another until he could set up a majelis taklim in his parents' house. The majelis, which he named Al-Irfan (wisdom), succeeded in drawing about two hundred attendees. However, his father, Habib Ja'far Assegaf, opposed Habib Hasan's majelis being based in the regency where his grandfather had been famous. He suggested that Habib Hasan should establish his majelis in another regency where he could build his own reputation (Mauladdawilah 2010: 53-54). Following a visit to the grave of the charismatic ulama Habib Ahmad b. Alwi Al-Haddad (well known as Habib Kuncung) in South Jakarta, Habib Hasan had a dream in which Habib Kuncung asked him to move to the capital in order to continue his religious preaching (Zamhari and Howell 2012: 57). 
Moving to South Jakarta, Habib Hasan started his dakwah among a small congregation of followers (jemaah). As a new preacher in the area, he visited local kyais and local figures to gain support for his majelis. Initially, the preaching activity took place in the houses of his students. As the number of participants began to increase to hundreds of people, however, Habib Hasan was forced to move his majelis to several mosques in Cilandak, South Jakarta (alKisah, February 24, 2008). Soon the number of participants grew too large even for the mosques; therefore, Habib Hasan decided to hold public preaching in open areas such as roads and fields (Mauladdawilah 2010: 91).

As the majelis gained more participants, Habib Hasan changed the name of his majelis from Al-Irfan (wisdom) to Majelis Nurul Musthofa (the Light of the Chosen man) in 2001, following a consultation with two charismatic habaib, Habib Umar b. Hafiz of Tarim, Yemen, and Habib Anis b. Alwi Al-Habsyi of Solo, Central Java, who made a visit to the majelis that year (Mauladdawilah 2010: 91, 96, 97). The term "Musthofa" (the Chosen One) refers to a name of the Prophet Muhammad, evidence that the majelis was using the Prophet as their symbol. This name change was considered to be a kind of 'spiritual authorisation' (ijazah) for Hasan to lead his majelis (Mauladdawilah 2010: 97; Zamhari \& Howell 2012: 58).

To promote his majelis, Habib Hasan formed a management team in 2002. The crew's main task was to help Habib Hasan in managing and promoting the majelis to a wider audience and, more importantly, creating new strategies for attracting young Muslims (alKisah, February 24, 2008: 125). To that end, Habib Hasan and his crew have employed a wide variety of publicity strategies. Several days before the majelis, for instance, the crew would erect long banners, billboards, and flags of their majelis along the streets near the advertised location of the coming event. The photos of Habib Hasan with his brothers and guest preachers featured prominently in the advertisement. The crew was also in charge of the production of religious merchandise such as jackets, key holders, stickers, posters, DVDs and books with the majelis logo or Habib Hasan's photo on them. On the day, a convoy of vehicles and motorcyclists would be organised to escort Habib Hasan to the location of the majelis. Habib Hasan would be riding at the front in a sedan guarded by police officers on motorcycles. There would also be fireworks to entertain young participants.

The leadership of the Majelis Nurul Musthofa rests with Habib Hasan and his brothers. Previously, Habib Hasan was the sole leader of the majelis, yet after his three brothers completed their studies, he called on them to play a greater role in the majelis. His brothers are Habib Abdullah b. Ja'far Assegaf, Habib Musthofa b. Ja'far Assegaf, and Habib Qasim b. Ja'far Assegaf. Habib Abdullah completed his senior high school in the Pesantren Dar al-Lughah wa al-Da'wa in Pasuruan, while the other brothers studied for 
some years in Hadhramaut. The presence of two of Habib Hasan's brothers who graduated from Hadhramaut has strengthened the religious authority of the majelis by connecting it to the centre of saints (wali) in Hadhramaut, Yemen. The growing demands of public preaching prompted Habib Hasan to divide the dakwah areas among his brothers. Their dakwah areas are known collectively as Jabodetabek (Jakarta, Bogor, Depok, Tangerang, and Bekasi). Habib Abdullah, for instance, is assigned to help Habib Hasan in South Jakarta; Habib Musthofa is assigned to be the leader of the majelis in Bogor, Ciawi, and Cibinong, while Habib Qasim is responsible for East Jakarta and surrounding areas such as Bekasi and Pondok Gede. ${ }^{7}$ Habib Hasan regularly invites local senior preachers such as KH. Abdul Hayyie Na'im ${ }^{8}$, KH. Abdul Rasyid Abdullah Syafi'i ${ }^{9}$, Habib Ali b. Abdurrahman Assegaf ${ }^{10}$, Habib Muhammad Rizieq b. Syihab ${ }^{11}$, KH. Adnan Idris ${ }^{12}$ and the late Ustadz

\section{Interview with Abdullah Assegaf, Jakarta, 13 June 2013.}

8. Son of Jakartan Ulama, KH. Muhammad Na'im (1912-1973), Abdul Hayyie studied at Pesantren Tebu Ireng, East Java, before going to Mecca to study at Dar al-'Ulum under the guidance of Syeikh Yasin Al-Fadani. Returning to Jakarta, he led the madrasah al-Nur and actively gave sermons in various majelis taklim in Jakarta. His short biography is available at https://www.nu.or.id/post/read/66695/kh-abdulhayyie-naim-santri-pengelana-di-jazirah-arab- (accessed 13 January 2019).

9. He is a popular preacher among traditionalist Muslims in Jakarta. He is the son of the charismatic ulama KH. Abdulah Syafi'i (1910-1985), who was the founder and leader of Perguruan Syafi'iyah (Islamic studies academy) that offered Islamic education from kindergarten to higher education level in Jakarta. Abdul Rasyid himself established an Islamic boarding school for Qur'anic studies, the Pesantren Al-Qur'an Asy-Syafi'iyah, in Sukabumi, West Java. His lineage to Abdullah Syafi'i has given him Islamic authority and popularity in Jakarta.

10. He is a popular habib among traditionalist Muslims in Jakarta. He is the son of the senior ulama Habib Abdul Rahman b. Ahmad Assegaf (1908-2007), who has established a center of informal Islamic education, the Madrasah Tsaqafah Islamiyah, an Islamic school that has been well known among traditionalist Hadhrami communities in Indonesia. Following his father's example, Habib Ali has established the Majelis Taklim Al-'Afaf, in Bukit Duri, South Jakarta.

11. Habib Rizieg is notorious for his leading role in Islamist activism and his harsh opposition to Indonesian government. He was the founder and supreme leader of the Islamic Defenders Front (Front Pembela Islam, FPI), an Islamist organisation that was established in 1998. Habib Rizieq was jailed several months for inciting hatred and violence. His reputation has been rising among Indonesian conservative Muslims in 2016 after his successful campaign, through the 212 movement, to prosecute the Christian Governor of Jakarta Basuki Tjahaya Purnama (well known as Ahok) on blasphemy charges. As a result, Ahok lost in the Gubernatorial election and ended in jail. In May 2017, Habib Rizieq fled to Saudi Arabia after being charged by Indonesian police for violating the pornography law and refused to return to his country. Although he is seen as an Islamist, Habib Rizieq is in fact traditionalist in his religious orientation and has often criticized Wahhabi teaching in his sermons. For good discussion on his dakwah movement, see Mark Woodward et.al (2012).

12. He is also a popular preacher among traditionalist Muslims in Jakarta. He is the leader of the Majelis Taklim Thursina, in Cilandak, South Jakarta. 
Jeffrie Al-Bukhari (1973-2013) ${ }^{13}$ (Mauladdawilah 2010: 90). The presence of these popular preachers adds variety and entertainment to performances that often last for three hours. Habib Hasan sometimes invites guest speakers from Hadhramaut who happen to be visiting Indonesia at the time. Preaching in the Arabic language, these guest speakers help to enhance the image of the majelis through their connection to the Middle East - the origin of Islam - as well as providing the majelis with religious legitimacy.

Nurul Musthofa has established itself as one of the biggest majelis with a large following among Muslim youth. In 2005, the majelis was transformed into a yayasan (foundation) and was formally registered as "Majelis Shalawat and Zikir Nurul Musthofa" with the Ministry of Religious Affairs of the Republic of Indonesia. The foundation is headed by Habib Hasan's brother, Habib Abdullah. Nurul Musthofa focuses on public preaching that takes place almost every night. Based on my observation, the public preaching of the majelis can attract tens of thousands of participants and in some occasions, especially at National Monuments, it can draw up to fifty thousand people. The majelis now has its own permanent building that functions as a centre of organisational operations as well as a place for regular preaching and praying. It is located behind the house of Habib Hasan in Ciganjur, South Jakarta. All equipment such as musical instruments, loud speakers, audio system tools, and banners are kept in that building. Some staff members live in that building and make all necessary preparations for the majelis.

\section{Performing Arab Saints (Wali)}

One distinctive aspect of the dakwah of new habaib is the promotion of sainthood (kewalian). Both sayyid status and the Arab ethnicity are expressed in the performance of a habib preacher. Sayyidness here refers to the genealogical link to the Prophet marked by the title "habib" (beloved) attached to the name of the preacher. In addition, particular clothing and visual attributes also represent outward marks of a habib. Their appearance also expresses their Arabness as they originated in Hadhramaut, Yemen. Many of their followers also remark favourably upon what they see as typical Arab traits, such as long sharp noses, beards, and dark complexion. Besides, several majelis use Arabic words on their banner on the stage.

The lineage to the Prophet endows the habaib with a special position in the Muslim community. Several books and posters sold in the majelis taklim as well as the stories told by the habaib preachers describe some sayyid ulamas in Indonesia's past as Muslim saints (wali) who not only played a major role in Islamisation but also possessed extraordinary spiritual powers.

13. He was a celebrity preacher who often gave sermons on national TVs. He was famous for his good singing voice and youth-style approach in preaching. He died in 2013 in a motorbike accident. 
The wali's graves are considered "keramat" (sacred) by many and have the power to give blessings to their visitors. According to Sumit Mandal, calling a specific burial place "keramat" is a form of respect from the community for the deceased because of "his outstanding spiritual piety, learning, historical accomplishments or some other notable distinctions" (Mandal 2012: 357). During my fieldwork in Jakarta and Java, I visited several sacred graves that attracted many visitors. The graves of popular saints in Jakarta, for instance, include those of Habib Ali b. Abdulrahman Al-Habsyi in Kwitang Jakarta, Habib Hasan b. Muhammad Al-Haddad and Habib Husein b. Abubakar Alaydrus in North Jakarta, and Habib Ahmad Al-Haddad in Kalibata South Jakarta. These graves have become popular destinations for young habaib preachers who include saint veneration in their majelis' regular program. Their visit is meant to bring blessings (baraka) from the dead saint and the hope that their prayers are answered by God due to the mediating role of the saints.

For traditionalist Muslims, habaib are considered as having inherited blessings (baraka) through their blood connection to the Prophet. The baraka for traditionalist Muslims can bring success and happiness or a way out of the problems in their lives. ${ }^{14}$ It is therefore not surprising to see Muslim participants in the majelis stand up when they meet a habib and flock to shake and kiss his hand hoping to get blessings from him. Some participants also bring a bottle of water and request the habib to recite prayers that would give the water healing powers or the power to solve any problem that might be troubling the participant.

A clear indication of descent from the Prophet is the attribution of title "habib" or "al-habib" before the name. In colonial times and early independence, the title "sayyid" (lord) was more popularly used in print rather than "habib". This is based on my reading of old newspapers and internal publications of Majelis Habib Ali Kwitang in Jakarta. Several habaib told me the usage of habib title is now more popular than sayyid in Hadhramaut and Indonesia. According to the chairman of Rabithah Alawiyah (the Alawi Union), Sayyid Zein b. Smith, the tittle of habib cannot be attributed to all descendants of the Prophet. He stated that every habib is sayyid, but not all sayyids can become habib. The recognition of habib has to come from a community with several requirements. To be a habib, a sayyid needs to be of mature age, erudite and learned in Islamic knowledge, implementing religious knowledge in practice, showing sincerity, fearing God (takwa), and applying Islamic ethics (akhlak). However, as mentioned above, the title is now increasingly used by many young sayyids for doing dakwah despite their limited knowledge of Islam and their lack of ethical qualities (Republika, 11 October 2014). This suggests that the new preachers realise the marketing value of the title in enhancing their

14. For further discussion on holy men and baraka in Islamic tradition, see Meri (1999) and Takim (2006). 
authority. This is also the case with the title "kiai"15 which is now routinely attributed to new preachers. The commodification of habib's title is clearly apparent from the advertisement media and websites that promote a new preacher figure of majelis taklim.

The sayyid communities have a family organisation, Rabithah Alawiyah that issues a genealogical book (buku nasab) for their members. Founded in 1928, the organisation serves to strengthen solidarity among sayyids with a primary concern for improving education and dakwah. One of its roles is to maintain genealogical records and formally issue a genealogical certificate. For those who want to obtain an official certificate of sayyid/sharifa, they need to apply to the Rabithah office and bring proof of their family connection in the line of their father. Some Rabithah staff worry that the booming popularity of habaib preachers leads to the commodification of habib status. ${ }^{16}$ They remark that some preachers in Jakarta and South Kalimantan use fake titles in order to promote themselves in the preaching market. However, they have not taken any action against this. Instead, they call on sayyid community to preserve their cultural and religious tradition. One of the ways is to apply for the genealogical book through Rabithah office. By having the book, the sayyids can show the proof of their lineage. This is important especially for maintaining the kafa'ah (equality in marriage) tradition within sayyid community, in which a female sayyid (sharifa) is required to marry a sayyid man who can prove his sayyidness through the genealogical book. ${ }^{17}$

Given the importance of genealogy for building religious legitimacy, many habaib preachers display the poster of their genealogy prominently in their houses or offices. The poster shows the names of male family descendants back to the Prophet Muhammad. Most habaib preachers I met claim they are the 38th to 40th generation descendants of the Prophet. According to Alwe Al-Mashoor, the family names of Alawiyyin total about 180 and those also reflect their sayyid identity (Al-Mashoor 2011: 175). Several family names of popular preachers in Indonesia include Al-Aththas, Al-Saqqaf, Shihab, Al-Habsyi, Al-Aydarus, Al-Kaff, b. Jindan, Al-Musawa, b. Yahya, Jamalullail, and Al-Jufri.

Apart from title and family name, dress is also important in expressing sayyidness. The habaib's clothes follow the old style of traditional ulama and saints (wali or sunan) in Indonesia. Habaib preachers often wear those as identity markers. Moreover, some preachers also bring siwak (tooth-cleaning stick made from tree twigs) in their pockets and use them before conducting a

15. Kiai simply means a traditional religious leader and scholar. In the past, it generally referred to a religiously learned man who both had the intellectual capacity to access Arabic books and led a traditional Islamic school (pesantren).

16. Interview with Muhammad and Ghazi Alaydrus, Jakarta, 18 June 2013.

17. Interview with Muhammad and Ghazi Alaydrus, Jakarta, 18 June 2013. 


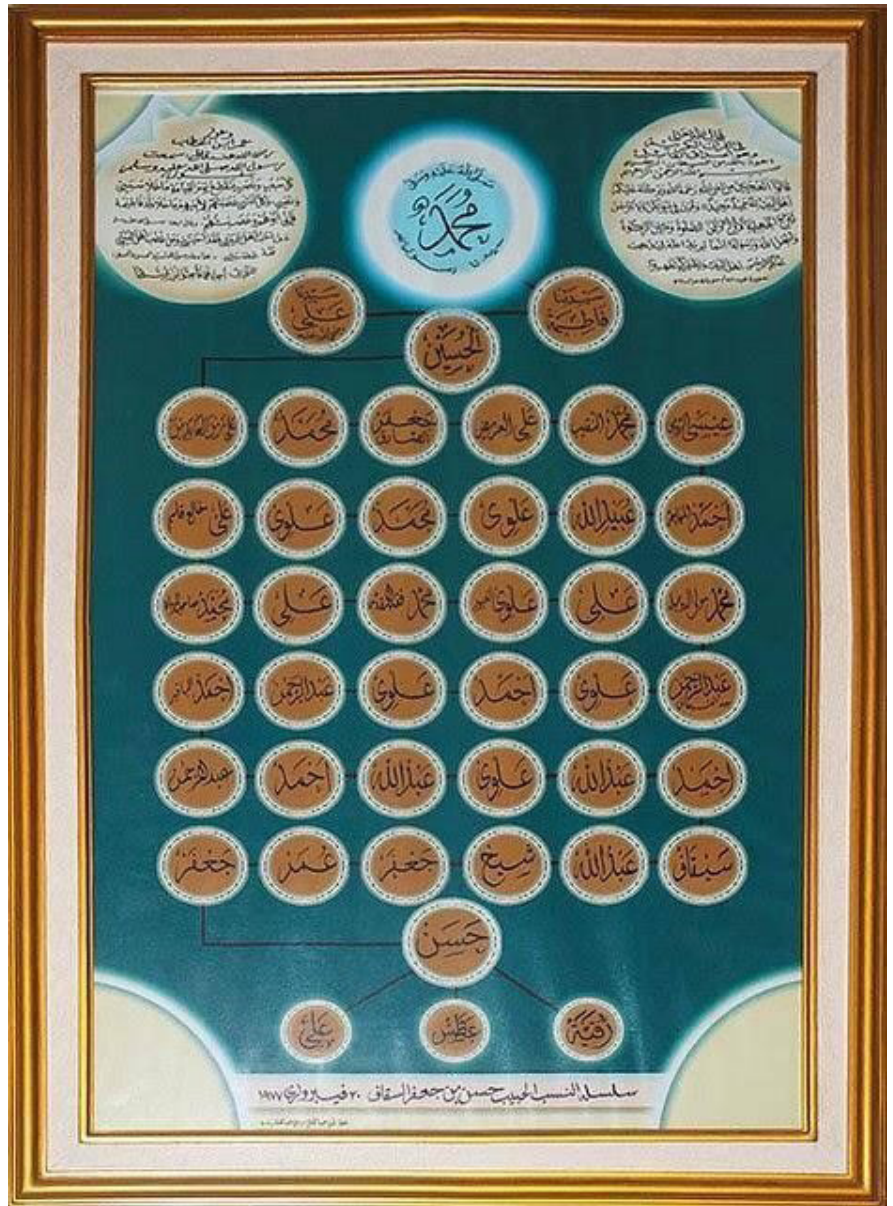

Fig. 2. A poster of the genealogical tree of Habib Hasan b. Ja'far Assegaf at his headquarter in South Jakarta. ${ }^{18}$

prayer. Habaib consider their style of clothing as imitating the clothes worn by the Prophet during his lifetime. I observed a popular habib preacher in Malang who suggested that his male followers should wear turbans as a symbol piety. He argued that the Prophet, his companions, and many ulamas in the past wore turbans during their lifetimes.

The traditional dress of habaib also replicates the appearance of Muslim saints who have been imagined through Indonesian movies and popular culture. They are portrayed wearing long robes and white turbans. The famous

18. This image is available at https://www.facebook.com/1817079845185959/photos/ a.1817428108484466/1817428111817799/?type=1\&theater (accessed 13 January 2020). 
Muslim saints in Java called 'the nine saints' (wali songo) are credited with spreading Islam in Java. While there are various versions of the origin of the saints, most habaib and a few Hadhami scholars (Alatas 1995; Shihab 2001) claim that the nine saints were originally from Hadhramaut and migrated to Southeast Asia for religious proselytising and trade. The tendency to claim sayyidness for 'the nine saints' is popularised in habaib owned magazines, most notably the alKisah magazine, and also in sermons. The habaib preachers often narrate their ancestor's struggles in Islamisation, their ethical principles, their spiritual exercises and miracles. By connecting with the past, the habaib seek to emphasise the important roles of their ancestors and their spiritual qualities to the congregation. On some occasions, preachers recount their dreams to their followers describing how they meet the Prophet and dead saints and receive messages and advice from them. The story of the late Habib Munzir's dream, for instance, was widely circulated among his followers after his death in 2013. Long before his death, Habib Munzir had told his followers that he saw the Prophet in a dream. In the dream, the Prophet suggested Habib Munzir take a rest from dakwah and promised that he would meet the Prophet at the age of forty. This dream was later interpreted as a prediction of Habib Munzir's death at the age of forty. This story was often related with pride by his brother, Habib Nabiel b. Fuad al-Musawa, and other habaib preachers, alluding to the miracle (karama) of Habib Munzir. Miraculous stories like this are common in Sufi literature, which bestows special status on Muslim saints. The dream narratives have been used by several preachers as a way of building their spiritual authority with Muslim followers.

\section{Mediating Spirituality with Musicality}

Many young habaib preachers have used new communication technology as an instrument in promoting their majelis and disseminating their messages to a wider audience. The use of new media, especially the internet, and advertising was started by the two largest majelis in Jakarta, namely the Majelis Nurul Musthofa and the Majelis Rasulullah. Both majelis began their dakwah expansion in 1998 in Jakarta. The majelis website is critical in promoting the habib leader or main preacher and his majelis. The home page of the Nurul Musthofa website, for instance, shows images of the habib appearing pious in traditionalist costume, praying or preaching to the congregation. The page provides various options such as a majelis profile, majelis programs and schedules, documentations of dakwah events, Islamic songs (qasidah) and prayers, social media links, Radio Live, YouTube channel and live streaming YouTube, and so forth. More recently, in 2019, the page also advertises pilgrimage travels to Mecca and Medina under the guidance of Habib Hasan and his brothers. The options in the website not only give information on majelis and religious messages, but also encourage audiences 
to engage in and support their dakwah through donations. On the website and social media, the sermons of habaib are accessible and people can watch live streamed preaching and listen to musical prayers. Besides, they provide online spaces for Muslim audiences to follow the ongoing activities of the majelis and take part online by posing questions and making comments related to the majelis program or theological matters.

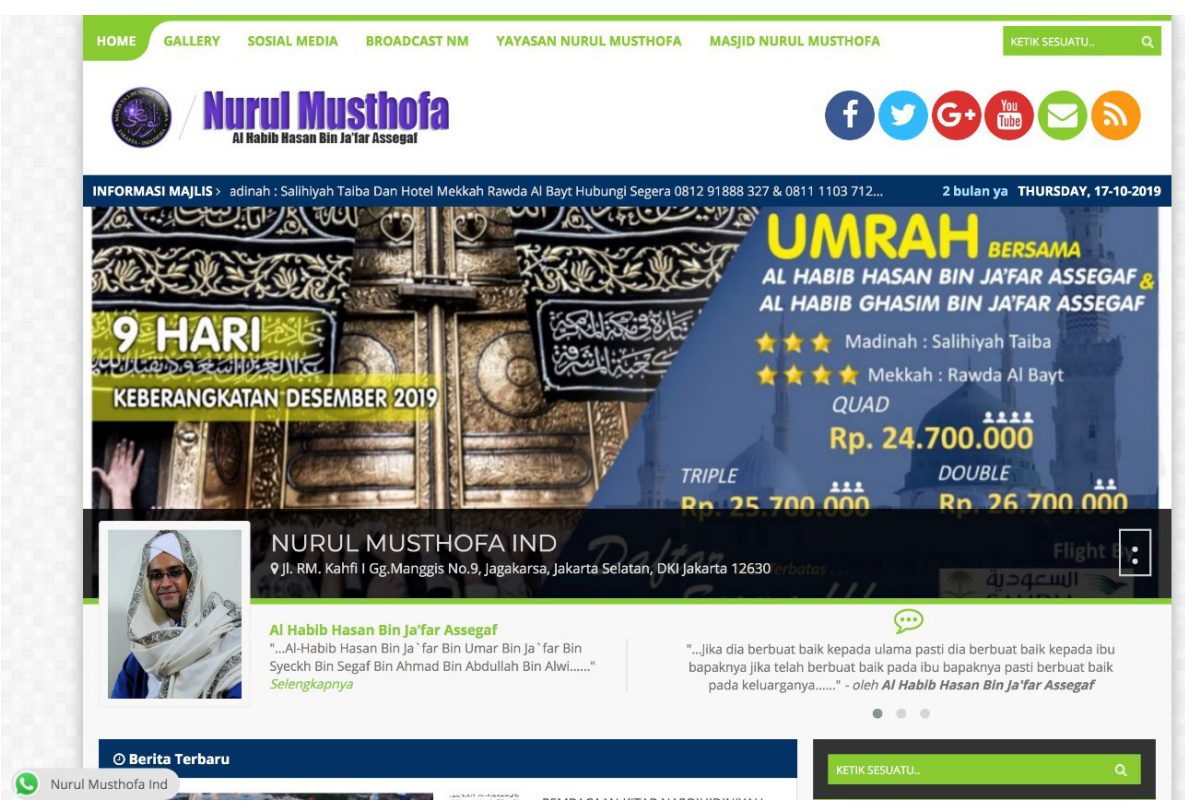

Fig. 3. The website of Nurul Musthofa.

The new media has enabled the creation of informal networks that link the followers of majelis taklim. The most popular media for young followers are mailing list, online communities in social media, and chat groups through smart phone. Some habaib fans have created community pages in social media to strengthen the bond among followers. Through online communities, followers can discuss and share their stories and impressions of their habib as well as sharing information on the forthcoming activities of the majelis. Moreover, they can mobilise their peers to attend majelis religious programs or social gathering. The followers of Majelis Rasulullah, for instance, have mobilised their fellows to attend public preaching or to organise solidarity meetings called "Kopi Darat" (Meet to know each other) in the house of their fellow volunteers. For the latter activity, they often invite the second rank habib and some staff of the Majelis Rasulullah to give a sermon at their own 
gatherings. ${ }^{19}$ The host of the meeting feels blessed due to the presence of a habib and believes that the recital of the Prophet's praises in his or her house can bring them more good fortune and prosperity.

The young habaib majelis emphasises ethical improvement and practical Sufi practices rather than black and white legal doctrine. This is very different from global Muslim movements, most notably Salafi, which emphasize a strict set of Islamic theology and Islamic law in their study groups. Habaib preachers in most events appeal to people to be pious through religious rituals and good deeds and avoiding sins. Their majelis provide more ritualistic activities than serious learning of particular religious texts (kitab). Many informants feel that they obtain tranquillity and peace when attending the majelis. One female follower of Majelis Nurul Musthofa stated:

I don't know why I was attracted to the majelis at first. The main thing is that when I come to the majelis, I feel peaceful and secure. I also feel free from any burdens and problems that I face in my life. What is more, when I join singing salawatan (sending praises to the Prophet), my tears cannot stop dropping. ${ }^{20}$

The distinctive part of the young habaib majelis is the recital of dzikir (remembrance of God) and salawat (praises to the Prophet) that can constitute up to half of the sermon activity. It is common for the participants to recite the prayers with great emotion, and some of them are moved to tears. During the recital participants usually hold in their hands the majelis' booklet containing a series of hagiographies of the Prophet, dzikr and salawat that are to be read during the preaching activity. Each majelis has produced its own recital booklet with their preacher's photo and logo on it. The Nurul Musthofa uses the hagiographic text written by the late Habib Ali b. Muhammad Al-Habsyi entitled Simth al-Durar (Chains of Pearls), while the Majelis Rasulullah uses the hagiographic text by the Yemeni Habib 'Umar b. Hafiz entitled al-Dhiya al-Lamiy (the Shimmering Light).

Arab traditional music (hadhrah) accompanies the chanting and preaching activities. The majelis has crew members assigned for chanting dzikir, salawat, and maulid texts, and singing Islamic songs. In Nurul Musthofa, the sermon is alternated with musical performance in order to avoid boring the congregation. The crew at the back play traditional musical instruments, such as tambourines and drums, with several vocalists singing the prayers and songs. The musical performance has become an important attraction for young participants to majelis. The leader of Nurul Musthofa has composed a number of religious songs which he adapted from popular Indonesian songs. ${ }^{21}$ The music has created an extravaganza that stimulates emotion and excites

19. Interview with Ahmad Fauzi, Jakarta, 5 October 2013.

20. Interview with Siska, Jakarta, 13 February 2013.

21. Interview with Muhiddin, Jakarta, 20 October 2013. 
the crowd. During the performance, some young followers wave their majelis' flags or swing their hands to the right and left while singing and enjoying the music as if they were in a music concert.

The leaders of majelis taklim have become superstars for Muslim youth due to the effect of their own media, advertisements, and performance. Selfpromotion through websites, books, billboards, and merchandises have helped to bolster the profile of habaib among their audience and the general public who access such media. The participants, who engage with habaib and are awed by their performance, religious messages, and pleasing personality, help to spread their image to the wider community. Some participants relate their experiences to friends and family in the social media, and this helps to spread the habaib's fame. Many followers of the majelis depict their preachers as holy men (wali), humble, pious, but also cool (keren). 'Coolness' in this sense means that habaib, although wearing a traditional garb, understand youth slangs and fancy style of speech and dress. Habib Hasan and his brothers in the Nurul Musthofa, for instance, often fascinate young participants by using the local dialect of Jakarta and slangs and wearing sunglasses. The sayyid status, self-promotion, and stylish performance have turned young habaib preachers into new idols for Muslim youths.

\section{Marketing the Prophet}

Young habaib have created a niche within the growing dakwah movements in Indonesia by identifying their movements as serving devotees of the Prophet Muhammad. Many of them have named their majelis taklim to emphasise the link with the Prophet: "Nurul Musthofa" (The Light of the Chosen One), "Majelis Rasulullah" (Assembly of the Prophet), "Ahbabul Musthofa" (The Lovers of the Chosen One), and "Waratsatul Musthofa" (the Inheritor of the Chosen One) to name but a few. The Majelis Rasulullah and Waratsatul Musthofa use the image of the Prophet's grave for their logo. They declare that their main concern of dakwah is to invite people to love the Prophet. They argue that in order to make people commit to the faith, young Muslims must first recognise and love the Prophet. To attract people to their religious sermon, habaib try to introduce Muhammad as a man through stories and Islamic songs instead of preaching about strict religious subjects. By introducing and preaching about Muhammad the Man, habaib hope that the congregation will make the Prophet the role model in their earthly lives. ${ }^{22}$ This missionary method resembles the new evangelical churches in the USA, which preach discipleship of Jesus by following His teachings and examples (Stassen 2012: 51).

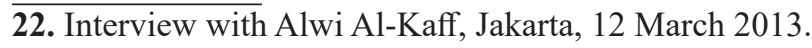



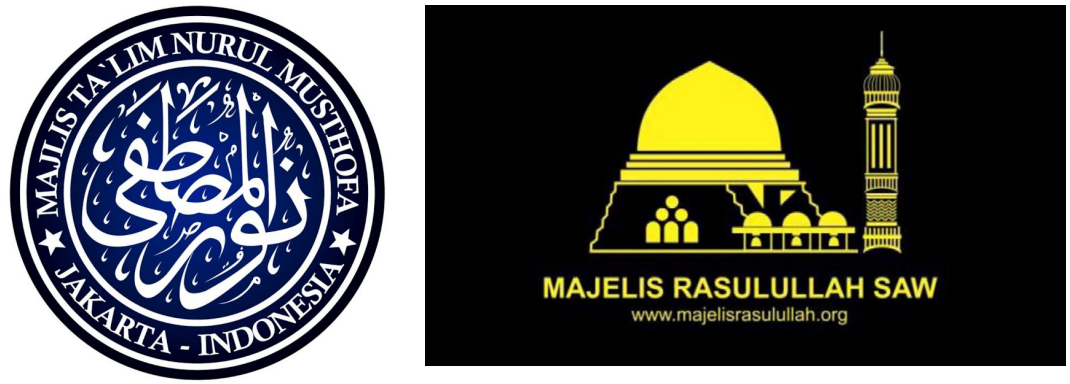

Fig. 4. Logo of Nurul Musthofa and Majelis Rasulullah.

Source: www.nurulmusthofa.org. and www.majelisrasulullah.org.

The love of the Prophet in habaib majelis is expressed in religious rituals and festivities that serve for remembering and sending praises to the prophet. The religious rituals associated with the Muslim traditionalists such as reciting praises to the Prophet (salawatan), celebrating the Prophet's birthday (maulid), and visiting saints' graves (ziarah) are framed as prophetic practices. This is different from reformist and Salafi groups which insist on the strict emulation of the Prophet in terms of religious practice and oppose unlawful innovations (bid'ah) that venerate the Prophet in the forms of maulid festivals and reciting praising texts to the Prophet. In several majelis taklim, the ritual of reading maulid texts usually precedes the preaching activities. Each majelis often celebrates the festivity of maulid in open area with thousands of participants. For habaib preachers, the maulid rituals are seen as a means to pleasing the Prophet. Some habaib and participants believe that the Prophet's spirit is present when maulid texts are recited. By reciting the praises of the Prophet, the congregation believe that they will get blessings for themselves and their families as well as gaining special help (shafa'at) from the Prophet in the hereafter regardless of their numerous sins.

Habaib use the symbols of the Prophet as branding in their religious marketing. According to Mara Einstein (2007: 70), branding is about "giving consumers something to think and feel about a product or service beyond its physical attributes". In Indonesia, various preachers and spiritual trainers have referred to the specific stories and sayings of the Prophet "in ways that resonate with the civic concerns, consumerist desires, and aspirational piety of the Muslim middle class" (Hoesterey 2012: 38-61). Aa Gym, for instance, when giving seminars and training on entrepreneurship, framed the Prophet as the role model of ethical entrepreneur who exemplified piety, trustworthiness, and initiative for achieving prosperity. This frame sought to show the Prophet as the measure of Muslim cosmopolitanism (Hoesterey 2012: 46). The habaib, however, brand their products as avenues for recognising and imitating the Prophet's personality and appearance. They argue that recognising the Prophet will lead people to deepen Islam and carry out its teachings. The 
religious products with various prophetic symbols (nabawi) are attractive to the followers of habaib. The retail outlet of Majelis Rasulullah (MR) calls itself "Kios Nabawi" (the Prophet's Kiosk). It sells books on how to follow the Prophet's ethics and prayers. There are also several books by Hadhrami scholars on maulid texts containing poems and praise to the Prophet. The MR staff argue that the marketing of the merchandise is a form of dakwah and the income is used for supporting the circle of majelis activities. ${ }^{23}$ By consuming these products, people identify themselves as the followers of habaib (muhibbin) and pious Muslims who help to ensure the survival of the Prophet's dakwah.

Considering that habaib are the family of the Prophet, the Prophet's branding can enhance the authority of habaib preachers. Therefore, it is not surprising that many of the habaib's sermons are related to the Prophet Muhammad. Many habaib draw attention to the compassion and moral virtues of the Prophet. By connecting the Prophet to their dakwah, habaib send the message that they are closer to the Prophet and that they are the legitimate heirs of the Prophet in preaching Islam. To strengthen their legitimacy before the umma, some habaib declare that they have met and received guidance from the Prophet through dreams and visions.

In the growing competitive market of habaib's dakwah, each majelis competes to provide a distinctive product that attracts young Muslim consumers. Habib Munzir of the Majelis Rasulullah, for instance, was a charismatic preacher who used literary, heartfelt, and heart-rending style (dari hati ke hati) in his sermons. His majelis is also the largest in terms of merchandising. Many followers claim that they have received knowledge and enlightenment after attending Habib Munzir's sermon. His experience of studying in Yemen and his attachment to Habib 'Umar of Yemen enhanced his authority among audiences. In the case of Habib Hasan of Nurul Musthofa, his strength lies in his accommodation of young people's aspirations and their strong liking for entertainment. The chanting and prayer singing of the lyrics composed by Habib Hasan are appealing to young followers, especially teenagers. Habib Hasan usually modifies Indonesian popular songs by changing their lyrics into religious ones. For his followers, the musical performance in the midst of sermons is more colourful and helps them avoid boredom when listening to preachers. Therefore, it is no wonder that many of his young followers are more amazed by the variety of fun and entertainment in the majelis than its sermons.

The popularity of majelis has enabled their leaders to develop a mutual interest with the state officials and politicians. Having a connection with the state officials is part of the social capital that habaib use in maintaining and advancing their majelis. On the one hand, the cooperation between the

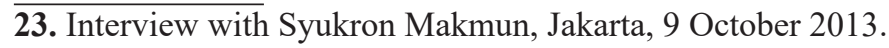


majelis and the state officials and politicians helps funding and facilitating the activities of the majelis as well as enhancing its image for Muslim audiences. Majelis staff admitted that there have been donations from various politicians and businessmen. The donations include money, cars for habaib and majelis operations, and rent payments for majelis headquarters. ${ }^{24}$ Both Nurul Musthofa and Majelis Rasulullah included former President Susilo Bambang Yudhoyono (SBY) and other government officials as advisory board members in the majelis. SBY himself established a majelis taklim, called Majelis Dzikir Nurussalam (The Light of Peace), which worked as a political venue for building his religious credentials among the umma. His own majelis also connected him to the networks of majelis taklim in Indonesia. During his presidency, his majelis often conducted a joint public preaching with habaib majelis, especially the Nurul Musthofa. The Nurul Musthofa staff stated that the joint activity with SBY's majelis was needed in order to gain support from the state in obtaining permission for public preaching as well as funding assistance for the development of the majelis. ${ }^{25}$ They claimed that their close connection to the state officials and local government has resulted in easy access to public areas, especially the Monas area, for organising particular events. Moreover, due to such a close relationship, the Nurul Musthofa often received invitations from SBY to deliver sermons or recite prayers in both his palace in Jakarta and his house in Cikeas, West Java. The closeness of habaib with the President and some ministers was also used by habaib to promote their majelis' name. For example, the pictures of important political figures often appear in the majelis' profile and banners.

On the other hand, the state officials and politicians use these events as a means to polish their religious image, especially before an election. Borrowing Kertzer's perspective on ritual, politics, and power, religious events serve as a ritual for "aspiring political leaders... to assert their right to rule, incumbent power holders seek to bolster their authorities" (Kertzer 1988: 1). Former President SBY often attended and delivered a speech at the Prophet's birthday festivals (maulid) held at the national monument in Jakarta. His attendance reinforced the image of a president who cared about Muslim aspirations. Apart from SBY, some ministers, politicians, and presidential candidates also attended the habaib majelis taklim. During the 2014 presidential election, many presidential candidates, such as Aburizal Bakrie (Golkar), Hatta Rajasa (PAN) and Muhaimin Iskandar (PKB), tried to woo Muslim voters who constitute the largest majority in Indonesia by attending majelis in Monas quarter in 2013. In the religious events, habaib usually mentioned their guests' names, praised their attendance, and asked the congregation to pray for their success in their political career. Although habaib did not declare their political support

24. Interview with Syukron Makmun, Jakarta, 9 October 2013.

25. Interview with Mahdali, Jakarta, 3 June 2013. 
for any particular candidate, the habaib's prayers and good wishes during the religious events were interpreted by their audience as political support.

The growing demand for public preaching in urban areas and the high financial rewards have benefitted religious preachers. Several studies have confirmed the success of preachers and trainers in capitalising their Islamic knowledge in big cities (Muzakki 2007; Hoesterey 2008 \& 2016; Howell 2008; Rudnyckyj 2010; Kailani 2015). As the centre of business and national media, Jakarta has enabled the creation of overnight celebrity preachers. Although all preachers claim their work is for the sake of dakwah, they have enjoyed financial rewards from the umma. Based on my observation and interviews in Jakarta, there are four sources of income of habaib in dakwah: honoraria from hosts, donations from the participants during public preaching, funding assistance from state officials and generous donators, and the income from selling their merchandise. Staff of Nurul Musthofa said that they charge about \$600-900 USD for public preaching for local areas (Jakarta) and more than that amount for areas outside Jakarta. They argue that this money is used for paying the preachers, hadhrah players and staff, as well as for providing the stage, speakers, musical instruments, and advertisements such as banners and billboards. Habib Abdullah of the Nurul Musthofa claims that in one dakwah performance he often gets about \$40-90 USD, an amount that he considered small after being shared with his three brothers and staff members. He rejected the rumours that their majelis requires tens of millions for dakwah. ${ }^{26}$ Despite this claim, his dakwah performance in Nurul Musthofa has made him popular among Jakartan Muslims. This popularity provides him with many personal invitations (outside his formal majelis) to give sermons at events in Jakarta such as wedding ceremonies, pengajian (religious study gathering), and other religious events.

\section{Conclusion}

This article has discussed sermon groups of young habaib as a new religious market in contemporary Indonesia. Focusing on Nurul Musthofa and relating it to other sermon groups, it has analysed the approaches habaib use in marketing tradition within expanding Islamic preaching industries in urban areas. While the emerging trend shows that most preachers use public speaking skills in religious markets, habaib also utilise performance in enhancing their religious authority and marketability. Their performance expresses a combination of traditionalism, sainthood, and Arabness. Using the internet and popular culture, the habaib promote themselves as living saints by capitalising on their sayyid status and emphasizing their ancestor's roles in Islamisation. In this regard, the using of habib titles, distinctive dress, and family names are of significance in expressing their status and Arab ethnicity.

26. Interview with Habib Abdullah Assegaf, Jakarta, 13 June 2013. 
By branding their majelis as the devotees of the Prophet, habaib have offered a new model of traditionalist piety among Muslim youths. Such branding implies that their dakwah is closer to the Prophet's mission, and therefore is more authentic and authoritative than other dakwah groups.

The case of habaib preachers suggests that tradition can be mediated and marketed in urban areas. This complements previous studies that largely focused on the modern dakwah expression within urban settings. The urban dakwah is usually tailored to appeal to a broad Muslim constituency. Furthermore, it tends to accommodate the modern tastes of the Muslim middle class and minimise traditionalist appearance and rituals. The habaib dakwah, however, is different and confronts this general pattern. Instead of being accommodative, their dakwah is targeted at a particular Muslim group. It promotes traditionalist Islam (aswaja) that only appeals to traditionalist Muslim communities culturally linked to the Nadhlatul Ulama. The habaib dakwah emerged at the 'right' time when there was a growing demand from traditionalist communities. Habaib have identified a market gap and moved into it, promoting devotional practices which meet the needs and aspirations of urban traditionalists. By using new media and religious markets, habaib not only succeed in popularising tradition, but they also gain elevated religious standing, fame, and financial rewards from the umma.

\section{References}

Abaza, M. (2004). "Markets of Faith: Jakartan Da'wa and Islamic Gentrification. Archipel, 67 (1), 173-202.

alKisah No. 04, February 11-24, 2008.

alKisah No. 20, September 30-October 13, 2013.

Al-Mashoor, A.A. (2011). Sejarah, Silsilah \& Gelar 'Alawiyin: Keturunan Imam Ahmad bin Isa Al-Muhajir. Jakarta: Maktab Daimi-Rabithah Alawiyah.

Alatas, IF. (2008). Securing Their Place: The Habaib, Prophetic Piety and Islamic Resurgence. MA Thesis. National University of Singapore.

Alatas, IF. (2011). "Becoming Indonesians: The Ba'Alawi in the Interstices of the Nation". Die Welt des Islams, 51, 45-74.

Alatas, S.F. (1997). "Hadhramaut and the Hadhrami Diaspora: Problems in Theoretical History". In U. Freitag and W. Clarence-Smith (eds.), Hadhrami Traders, Scholars and Statesmen in the Indian Ocean, 1750s-1960s (pp. 19-34). Leiden, New York, Köln: E.J. Brill.

Al-Musawa, I.F. (2014). Meniti Jalan Pemuda Nabawi: Biografi Pendiri Majelis Rasulullah Saw Habib Munzir bin Fu'ad Almusawa. Jakarta: Majelis Rasulullah.

Badan Kontak Majelis Taklim (BKMT). (2019). Sejarah BKMT. Retrieved 2 October 2019, from http://bkmt.or.id/index/sejarah-bkmt/

Chaplin, C. (2018). "Salafi Activism and the Promotion of a Modern Muslim Identity: Evolving Mediums of Da'wa amongst Yogyakartan University Students". Southeast Asia Research, 26(1), 3-20.

De Witte, M., de Koning, M., \& Sunier, T. (2015). "Aesthetics of Religious Authority: An Introduction". Culture and Religion, 16 (2), 117-124.

Einstein, M. (2008). Brands of Faith: Marketing Religion in Commercial Age. London and New York: Routledge. 
Fealy, G. \& White, S. (eds.). (2008). Expressing Islam: Religious Life and Politics in Indonesia. Singapore: Institute of Southeast Asian Studies.

Guntur \& Tim Majelis Rasulullah. (2013). Habib Munzir Menanam Cinta untuk Para Kekasih Rasulullah. Jakarta: Qultum Media.

Hasan, N. (2006). Laskar Jihad: Islam, Militancy, and the Quest for Identity in Post-New Order Indonesia. Ithaca: Cornell Southeast Asian Program.

Hew, Wai Weng (2018). Chinese Ways of Being Muslim: Negotiating Ethnicity and Religiosity in Indonesia. Copenhagen K, Denmark: NIAS Press.

Hoesterey, J.B. (2012). "Prophetic Cosmopolitanism: Islam, Pop Psychology, and Civic Virtue in Indonesia". City and Society, 24(1), 38-61.

Hoesterey, J.B. (2016). Rebranding Islam: Piety, Prosperity, and A Self-Help Guru. California: Stanford University Press.

Howell, J. (2008). "Modulations of Active Piety: Professors and Televangelists as Promoters of Indonesian Sufism". In G. Fealy \& S. White (eds.), Expressing Islam: Religious Life and Politics in Indonesia (pp. 63-85). Singapore: Institute of Southeast Asian Studies.

Jahroni, J. (2015). The Political Economy of Knowledge: Salafism in Post-Soeharto Urban Indonesia. $\mathrm{PhD}$ thesis, Boston University.

Kailani, N. (2015). Aspiring to Prosperity: The Economic Theology of Urban Muslims in Contemporary Indonesia. $\mathrm{PhD}$ thesis, University of New South Wales.

Kalmbach, H. (2015). "Blurring Boundaries: Aesthetics, Performance, and the Transformation of Islamic Leadership". Culture and Religion, 16(2), 160-174.

Kertzer, D.I. (1988). Ritual, Politics, and Power. New Haven and London: Yale University Press.

Kitiarsa, P. (Ed.). (2008). Religious Commodification in Asia: Marketing Gods. London and New York: Routledge.

Majelis Rasulullah. (n.d.). Profil Majelis Rasulullah. Available at http://majelisrasulullah.org/ index.php?option=com_content\&task=view\&id=2\&Itemid=26 (accessed 15 April 2013).

Mandal, S.K. (1994). Finding Their Place: A History of Arabs in Java under Dutch Rule, 18001924. $\mathrm{PhD}$ thesis, Columbia University.

Mauladdawilah, A.Q.U. \& Mauladdawilah, A.Q.A.. (2010). Dakwah Pemuda Ibu Kota. Malang: Pustaka Basma.

Meri, J.W. (1999). "Aspects of Baraka (Blessings) and Ritual Devotion Among Medieval Muslims and Jews". Medieval Encounters, 5(1), 46-69.

Meuleman, J. (2011). "Dakwah, Competition for Authority, and Development". Bijdragen tot de Taal-, Land-en Volkenkunde, 167(2/3), 236-269.

Millie, Julian. (2012). "Oratorical Innovation and Audience Heterogeneity in Islamic West Java". Indonesia, 93, 123-145.

Muzakki, A. (2008). "Islam as a Symbolic Commodity: Transmitting and Consuming Islam through Public Sermons in Indonesia". In P. Kitiarsa (ed.), Religious Commodifications in Asia: Marketing God (pp. 205-219). London and New York: Routledge.

Nuhrison, M.N. (2010). "Gerakan Paham dan Pemikiran Islam Radikal Pasca Orde Baru (Gerakan Dakwah Salafi di Kec. Lembar, Kab. Lombok Barat, Nusa Tenggara Barat)". In W. Sugiyarto (ed.), Direktori Kasus-Kasus Aliran, Pemikiran, Paham, dan Gerakan Keagamaan di Indonesia. Jakarta: Kementerian Agama RI Badan Litbang dan Diklat Puslitbang Kehidupan Keagamaan.

Republika. (2014). "Salah Kaprah Sebutan Habib di Masyarakat". Available at http://www. republika.co.id/berita/nasional/umum/14/10/11/nd9vk0-salah-kaprah-sebutan-habib-dimasyarakat (accessed 15 December 2014).

Rudnyckyj, D. (2010). Spiritual Economies: Islam, Globalization, and the Afterlife of Development. Ithaca: Cornell University Press.

Saparudin \& Emawati (2018). Masjid dan Fragmentasi Sosial: Pencarian Eksistensi Salafi 
di Tengah Mainstream Islam di Lombok. Pusat Penelitian dan Publikasi Ilmiah Lembaga Penelitian dan Pengabdian kepada Masyarakat Universitas Islam Negeri Mataram.

Sunarwoto. (2016). "Salafi Dakwah Radio: A Contest for Religious Authority". Archipel, 91, 203-230.

Shihab, A. (2001). Islam Sufistik: Islam Pertama dan Pengaruhnya Hingga Kini di Indonesia. Bandung: Mizan.

Stassen, G.H. (2012). "God's Vision for the Church-Kingdom Discipleship". In Gushee, D.P. (ed.). A New Evangelical Manifesto: A Kingdom Vision for the Common Good (pp. 50-56). St. Louis, Mo.: Chalice Press.

Takim, L. N. (2006). The Heirs of the Prophet: Charisma and Religious Authority in Shi'ite Islam. Albany: State University of New York Press.

Wahid, Din. (2014). Nurturing The Salafi Manhaj: A Study of Salafi Pesantren in Contemporary Indonesia. $\mathrm{PhD}$ dissertation, Utrecht University.

Winn, Phillip. (2012). "Women's Majelis Taklim and Gendered Religious Practice in Northern Ambon". Intersections: Gender and Sexuality in Asia and the Pacific, 30, November 2012. Available at http://intersections.anu.edu.au/issue30/winn.html (accessed 10 March 2015).

Woodward, M. et. al. (2012). "Ordering What is Right, Forbidding What is Wrong: Two faces of Hadhrami Dakwah in Contemporary Indonesia". Review of Indonesian and Malaysian Affairs, 46(2), 105-146.

Zamhari, A. \& Howell, J.D. (2012). "Taking Sufism to the Streets: Majelis Zikir and Majelis Salawat as New Venues for Popular Islamic Piety in Indonesia". Review of Indonesian and Malaysian Affairs, 46(2), 47-75. 
